\title{
Effects of Laboratory Incubation on the Available Phosphorus Content of Soil
}

\author{
${ }^{1} \mathrm{~K}$. SÁRDI, ${ }^{2}$ P. CSATHÓ, ${ }^{1}$ I. SISÁK, ${ }^{2}$ E. OSZTOICS, ${ }^{1} \mathrm{P}$. SZÜCS \\ and ${ }^{1}$ Á. BALÁZSY \\ ${ }^{1}$ University of Veszprém, Georgikon Faculty of Agriculture, Keszthely and \\ ${ }^{2}$ Research Institute for Soil Science and Agricultural Chemistry of the \\ Hungarian Academy of Sciences, Budapest
}

\section{Introduction}

Influences of residual phosphorus play an important role in the effectiveness of fertilization. It is also known that crops may differ in their ability of accessing either freshly applied or residual P in soils. Due to this fact problems may arise in studying the residual value of phosphorus fertilization in various soils.

Estimation of the residual value is frequently uncertain, as results are not transferable among soils having different characteristics, such as $\mathrm{pH}$, adsorption and buffering capacity, organic matter content etc. (BARROW, 1980).

The characterization of short-term transformation processes is required for the better understanding of certain parts of $\mathrm{P}$ cycling. For agronomic purposes it is necessary to determine the plant available forms of phosphorus, using several extracts suitable for routine soil testing. Test values obtained in these extracts have been calibrated and correlated for a wide range of soils with various soil characteristics (WOLF \& BAKER, 1985). For these routine soil tests, numerous methodologies with various modifications (more than 50 methods) are used world-wide, the most common extractants are the alkaline $(\mathrm{pH}=8.5)$ bicarbonate extractant developed by OLSEN et al. (1954) and the acidic ammonium fluoride solution of BRAY and KURTZ (1945), Bray 1, Bray 2, the Mehlich extractants and others. One of the acidic extractants, the ammonium lactate $(\mathrm{AL}, \mathrm{pH}=3.7)$ solution, introduced by EGNER et al. (1960) is commonly used in Europe (also the standard method in Hungary since the 1970's).

The main objective of the present experiment was to study the changes in the amounts of available phosphorus as influenced by residual and freshly added $\mathrm{P}$

- after incubation for two periods at different temperatures, and

- in different extracts. 


\section{Materials and Methods}

Incubation experiments were carried out for studying the changes in plant available $\mathrm{P}$ forms after 2 days and 60 days at $10{ }^{\circ} \mathrm{C}$ and $40^{\circ} \mathrm{C}$ temperature.

Soil samples were taken from selected plots of a long-term fertilization field trial conducted on a pseudogleyic brown forest soil at Szentgyörgyvölgy, located in the Western Transdanubian region of Hungary. The soil has a silt loam texture, and can be classified as a Stagnic luvisol according to the FAO taxonomy or Typic Albaqualf according to the USA taxonomy, with $21 \%$ clay and $2.3 \%$ humus content. Soil $\mathrm{pH}$ was nearly neutral $\left[\mathrm{pH}\left(\mathrm{H}_{2} \mathrm{O}\right)\right]$ or in the moderately acidic interval $[\mathrm{pH}$ $(\mathrm{KCl})$ ], therefore soil acidity was not expected to decrease the effectiveness of $\mathrm{P}$ fertilization significantly.

The ten-year intensive fertilization resulted in three increasing levels of P (referred to as P0, P1 and P2). Total amounts of phosphorus applied during the tenyear period for the P0, P1 and P2 level were 0,1032 and $1968 \mathrm{~kg} \mathrm{P}_{2} \mathrm{O}_{5} \cdot \mathrm{ha}^{-1}$ (BALÁZS \& NÉMETH, 2002).

The availability of phosphorus in the soil samples was rather poor in the case of each long-term $\mathrm{P}$ level at the start of the incubation experiment. Some selected characteristics of the experimental soil are summarized in Table 1.

Changes in the amounts of available phosphorus were determined in four freshly applied new treatments with increasing rates of phosphorus $(0,100,500$ and 1000 mg $\mathrm{P}_{2} \mathrm{O}_{5} \cdot \mathrm{kg}$ soil $^{-1}$ ), representing agronomic and extreme $\mathrm{P}$ rates to be studied for environmental considerations.

$\mathrm{P}$ treatments were applied in the form of finely ground superphosphate $(18 \%$ $\mathrm{P}_{2} \mathrm{O}_{5}$ ). Soil moisture was kept at $70 \%$ water holding capacity (WHC) during the incubation.

Available soil phosphorus contents were determined using three extraction methodologies: in water (water-P) according to the modified Murphy-Riley method (MURPHY \& RILEY, 1962), in ammonium hydrocarbonate (Olsen-P) at $\mathrm{pH}=8.5$ (OlSEN \& SOMMERS, 1982), and in ammonium lactate (AL-P), at $\mathrm{pH}=3.7 \pm 0.05$ (EGNER et al., 1960). Amounts of available P were determined by colorimetry, measuring the blue phospho-molybdate complex.

Table 1

Main characteristics of the experimental soil

\begin{tabular}{|c|c|r|r|r|r|r|r|}
\hline \multirow{2}{*}{$\begin{array}{c}\text { Long-term } \\
\text { P level }\end{array}$} & \multicolumn{2}{|c|}{$\mathrm{pH}$} & Water-P & Olsen-P & AL-P & AL-K & $\mathrm{N}_{\text {min }}$ \\
\cline { 2 - 8 } & $\mathrm{H}_{2} \mathrm{O}$ & $\mathrm{KCl}$ & \multicolumn{5}{c|}{$\mathrm{mg} \cdot \mathrm{kg}^{-1}$} \\
$\mathrm{P} 0$ & 6.72 & 6.14 & 8.8 & 22.96 & 44.77 & 112.8 & 31.8 \\
$\mathrm{P} 1$ & 6.54 & 5.93 & 10.7 & 39.16 & 66.76 & 117.4 & 19.82 \\
$\mathrm{P} 2$ & 6.60 & 6.16 & 13.17 & 40.62 & 69.30 & 105.4 & 17.22 \\
\hline
\end{tabular}

Remarks: Amounts of $\mathrm{P}$ and $\mathrm{K}$ are expressed in $\mathrm{P}_{2} \mathrm{O}_{5}$ and $\mathrm{K}_{2} \mathrm{O}$, respectively, throughout the paper 
Results of incubation experiments carried out with the soil samples of the fertilization trial on an Orthic Eutrochrept soil at Keszthely with the same fertilizer rates were reported recently (SARDI et al., 2005).

\section{Results and Discussion}

\section{Effect of short-term incubations on the changes in available P amounts}

Results of laboratory analyses obtained after 2 and 60 days of incubation are shown in Figs. 1-3.

Residual effects of intensive phosphorus fertilization could be observed even after 30 years in the amounts of available $\mathrm{P}$ determined in the three extracts.

From the results it was evident that the order of available $\mathrm{P}$ amounts was as follows at each long-term P level: AL-P > Olsen-P $>$ water-P.

It could be observed that phosphorus amounts were considerably higher in the AL extract, especially at the lower temperature $\left(10^{\circ} \mathrm{C}\right)$. Extremely high $\mathrm{P}$ additions have resulted in dramatic increases in available phosphorus contents of soil samples, with the maximum of $784.5 \mathrm{mg} \mathrm{P}_{2} \mathrm{O}_{5} \cdot \mathrm{kg}^{-1}$ soil at the $\mathrm{P} 2$ long-term level after 60 days of incubation. The higher temperature $\left(40{ }^{\circ} \mathrm{C}\right)$ markedly influenced available soil $\mathrm{P}$ contents.

Changes in the available $\mathrm{P}$ content after the incubation periods showed similar tendencies in all of the freshly applied treatments.

In the unfertilized control treatment:

- After short-term incubation at $10{ }^{\circ} \mathrm{C}$, significant increases could be observed in the water-P amounts as compared to the initial values. After 60 days, some decreases occurred.

- Incubation at the high temperature resulted in significant increases in available phosphorus in each of the extracts.

With the increasing rates of $P$ additions: amounts of water-P showed decreases at both temperatures after the incubation periods.

Amounts of Olsen-P showed increases at $10^{\circ} \mathrm{C}$ in each freshly applied treatment, with the exception of the unfertilized control at the P0 long-term level.

Olsen-P values were significantly higher after 2 days of incubation at $40{ }^{\circ} \mathrm{C}$ in the unfertilized control as well as in the other treatments.

On the other hand, after 60 days of incubation at $40{ }^{\circ} \mathrm{C}$, Olsen extractable fractions of soil $\mathrm{P}$ were significantly lower at each long-term $\mathrm{P}$ level in each treatment, with the exception of P500 and P1000 treatments at the P2 level. This could be related to the $\mathrm{pH}$ conditions during this extraction methodology and possibly also to that $\mathrm{P}$ additions in these treatments exceeded the measure of $\mathrm{P}$ immobilization.

Similar tendencies were observed in the changes of ammonium lactate soluble phosphorus $(A L-P)$ contents of soil. In comparison to the initial values, amounts of AL-P were lower at both temperatures after 2 days of incubation in the unfertilized control. After 60 days of incubation, however, considerable increases of AL-P val- 

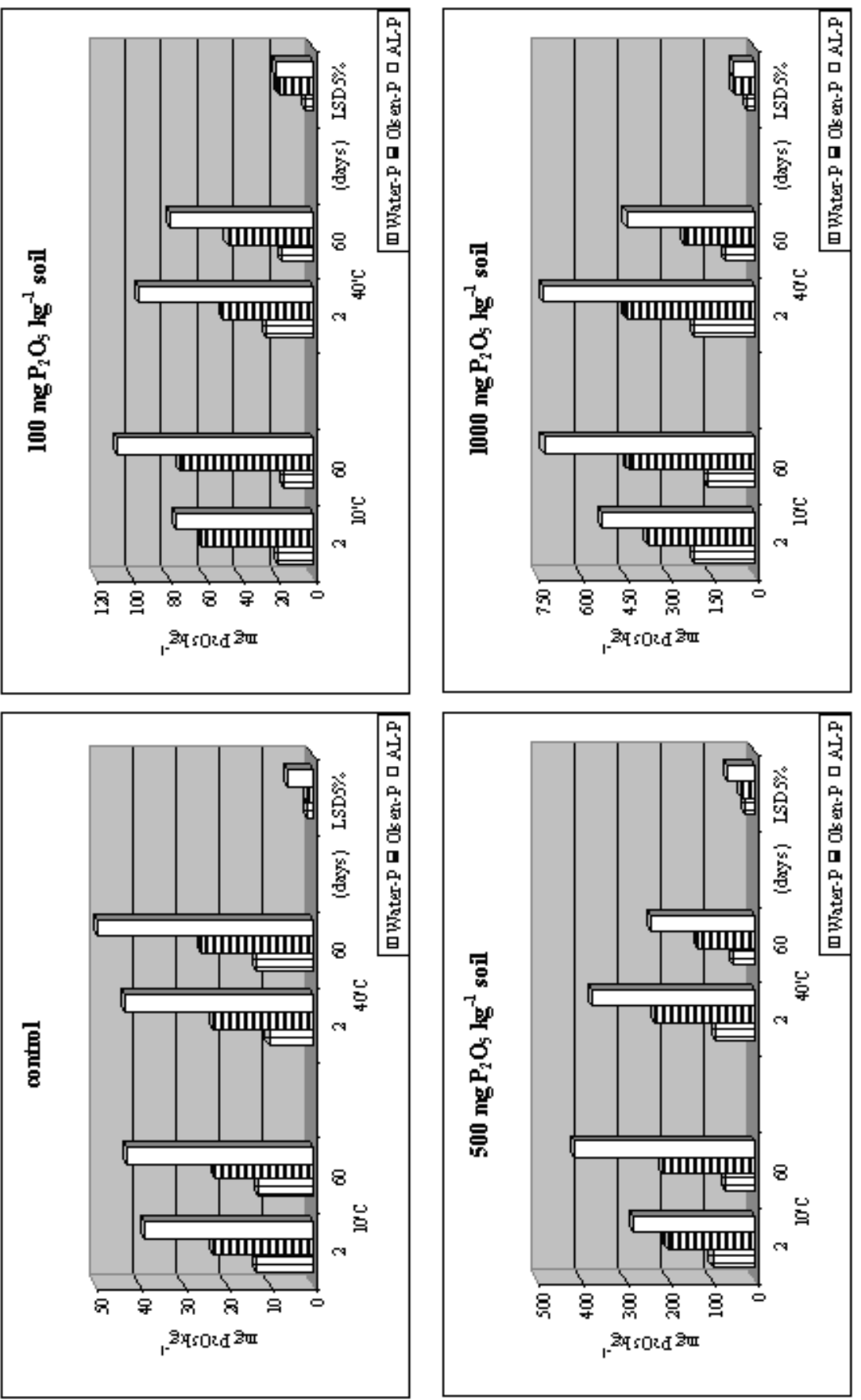

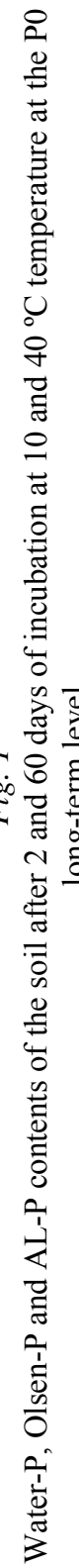



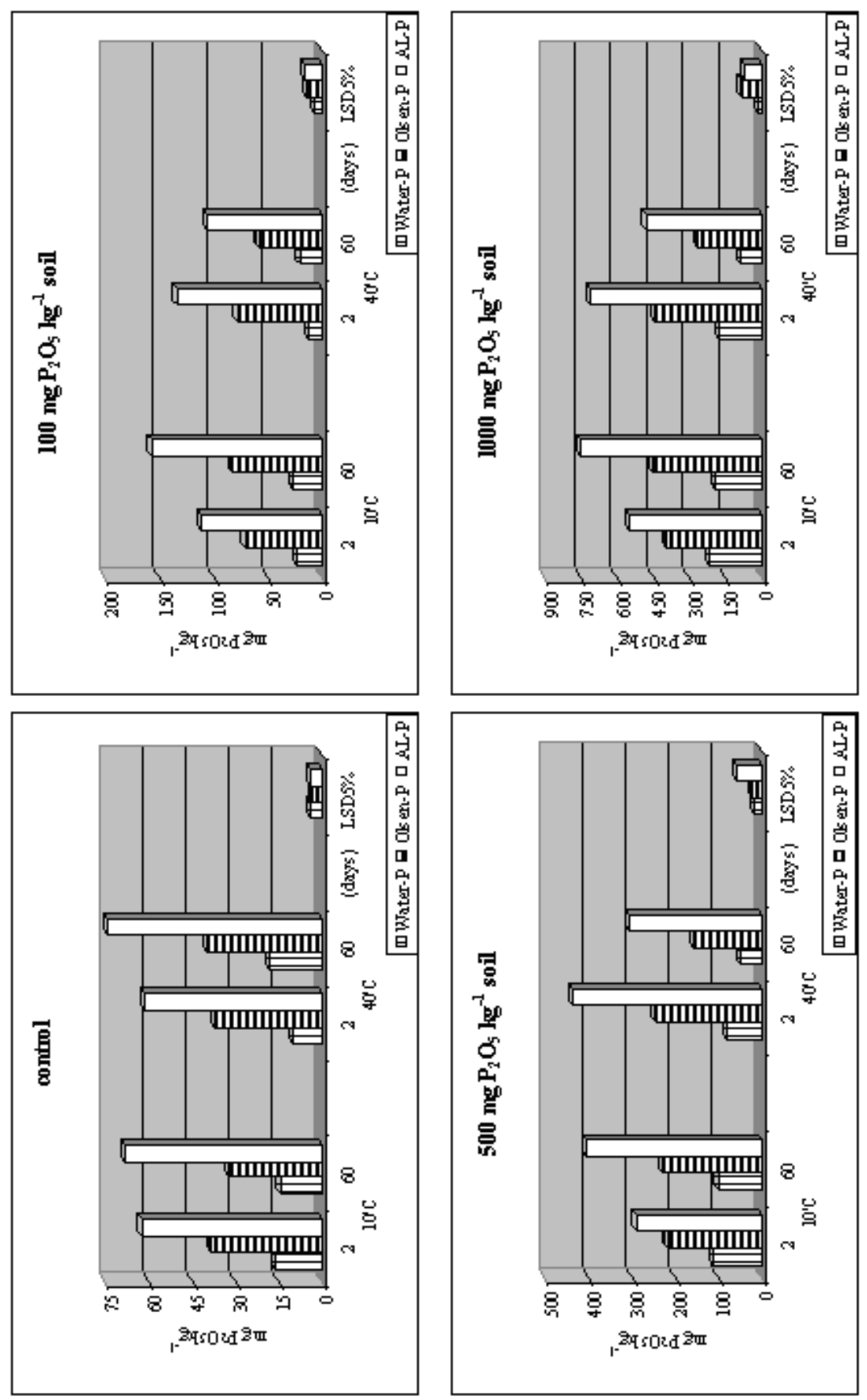

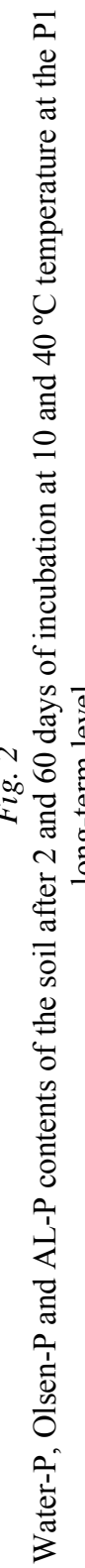





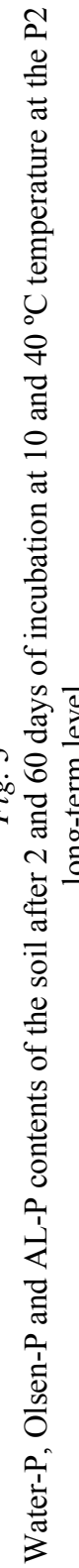


ues were recorded. Differences were significant in most treatments (see the Figures).

On the contrary, incubation at $40{ }^{\circ} \mathrm{C}$ seemed to favour the immobilization of available $\mathrm{P}$ forms: amounts of Olsen-P were consistently and significantly lower after 60 days of incubation at this temperature.

\section{Comparison of soil test values obtained in the three different extracts}

Soil test values measured after 2 and 60 days of incubation at the two temperatures $\left(10\right.$ and $\left.40{ }^{\circ} \mathrm{C}\right)$ in the three extracts were correlated (water $\mathrm{P}-$ Olsen $\mathrm{P}$, water $\mathrm{P}-\mathrm{AL} \mathrm{P}$ and Olsen P - AL P, respectively). Results of the statistical analyses are summarized in Table 2.

From the results it was evident that correlations between the soil $\mathrm{P}$ test values were highly significant even at the $\mathrm{P}=0.000 \%$ level in each case $\left(\mathrm{R}^{2}\right.$ values ranged between 0.7682 and $0.9672, \mathrm{n}=48$ ). The closest correlation - described by a quadratic equation - was found between water-P and Olsen-P values at both temperatures and incubation time intervals (see Table 2).

\section{Conclusions}

The residual effects of intensive phosphorus fertilization were observable even after 30 years in the amounts of available $P$ determined in the three extracts.

The incubation experiment results show that available soil $\mathrm{P}$ contents were significantly increased by increasing $P$ rates applied in the freshly added treatments.

At lower temperature higher amounts of available phosphorus were measured by using the acidic $(\mathrm{pH}=3.7) \mathrm{AL}$ extractant.

At $40{ }^{\circ} \mathrm{C}$ temperature, water soluble $P$ amounts significantly decreased in all treatments (except in the unfertilized control).

Table 2

Relationships among the soil test values measured in the different extracts after 2 and 60 days of incubation at 10 and $40{ }^{\circ} \mathrm{C}$ temperature

\begin{tabular}{|l|c|c||c|c|}
\hline \multirow{2}{*}{ Extractants } & \multicolumn{2}{|c||}{ After 2 days of incubation } & \multicolumn{2}{c|}{ After 60 days of incubation } \\
\cline { 2 - 5 } & Equation $(\mathrm{n}=48)$ & $\mathrm{R}^{2}$ & Equation $(\mathrm{n}=48)$ & $\mathrm{R}^{2}$ \\
\hline \multicolumn{5}{|c}{ Incubation at $10^{\circ} \mathrm{C}$} \\
Water P - Olsen P & $\mathrm{y}=1.786 \mathrm{x}+10.265$ & 0.8844 & $\mathrm{y}=2.3579 \mathrm{x}+4.6105$ & 0.9469 \\
Water P - AL P & $\mathrm{y}=2.2685 \mathrm{x}+19.798$ & 0.9143 & $\mathrm{y}=3.5678 \mathrm{x}+18.452$ & 0.8959 \\
Olsen P - AL P & $\mathrm{y}=1.1985 \mathrm{x}+12.235$ & 0.9205 & $\mathrm{y}=1.5199 \mathrm{x}+10.869$ & 0.9546 \\
Water P - Olsen P & $\mathrm{y}=1.9118 \mathrm{x}+10.872$ & 0.8394 & $\mathrm{y}=2.6925 \mathrm{x}+3.8034$ & 0.9143 \\
Water P-AL P & $\mathrm{y}=3.653 \mathrm{x}+24.696$ & 0.8796 & $\mathrm{y}=4.7935 \mathrm{x}+6.1502$ & 0.9178 \\
Olsen P - AL P & $\mathrm{y}=1.6359 \mathrm{x}+24.054$ & 0.7682 & $\mathrm{y}=1.7476 \mathrm{x}+1.0939$ & 0.9672 \\
\hline
\end{tabular}

Remarks: level of significance: $\mathrm{P}=0.000$ 
Tendencies in the changes in Olsen-P and AL-P amounts were similar and strongly responded to temperature. The 60 days incubation period had favoured the availability of soil $\mathrm{P}$. This trend appears in the soil test values at each long-term $\mathrm{P}$ level.

On the other hand, high temperature and the constant moisture seemed to be favourable for the short-term immobilization of available phosphorus forms in the Typic Albaqualf soil.

From the close correlations among the soil test values of the three extraction methodologies studied it can be concluded that, as these extractants represent various $\mathrm{pH}$ conditions, the results obtained may give transferable information on the amounts of available soil $P$.

These studies are of practical importance in the wider understanding of phosphorus dynamics in soils.

The present study was supported financially by the Hungarian National Scientific Research Fund (OTKA under grant No. T 042665).

Key words: available soil $\mathrm{P}$, incubation experiment, $\mathrm{P}$ fertilization field trials

\section{References}

BALÁZS, J. \& NÉMETH, I., 2002. Effects and residual effects of intensive P fertilization during the 1960's. (In Hungarian) In: Proc. Conf. on Environmental Hazards and the Respiratory System, Hévíz. 7-17.

BARROW, N. J., 1980. Evaluation and utilization of residual phosphorus in soils. In: The Role of Phosphorus in Agriculture. Chapter 13. 333-359. SSSA, Madison, WI.

BRAY, R. H. \& KURTZ, L.T., 1945. Determination of total, organic and available forms of phosphorus in soils. Soil Sci. 59. 39-45.

EgNeR, H., RiEM, H. \& DOMINGO, W., 1960. Untersuchungen über die chemische Bodenanalyse als Grundlage für die Beurteilung des Nährstoffzustandes der Böden. II. Chemische Extractionsmethoden zur Phosphor und Kaliumbestimmung. Kungl. Lantbrukshögsk. Ann. 26. 199-215.

MuRPhy, J. \& RILEY, J. P., 1962. A modified single solution method for the determination of phosphate in natural waters. Anal. Chim. Acta. 27. 31-36.

Olsen, S. R. \& SOMmers, L. E., 1982. Phosphorus. In: Methods of Soil Analysis, Part 2. Chemical and Microbiological Properties. (Eds.: PAge, A. L., MilLER, R. H. \& KEENEY, D. R.) 403-430. American Society of Agronomy. Madison.

OlsEn, S. R. et al., 1954. Estimation of Available Phosphorus in Soil by Extraction with $\mathrm{NaHCO}_{3}$. U.S. Dep. Agric. Circ. No. 39. USDA. Washington, D. C.

SÁRDI, K., CSATHÓ, P. \& OsZTOICS, E., 2005. Changes in the soil phosphorus content of a long-term fertilization field trial studied in laboratory incubations. Commun. Soil Sci. Plant Anal. (In press)

WOLF, A. M. \& BAKER, D. E., 1985. Comparisons of soil test phosphorus by Olsen, Bray P1, Mehlich-I and Mehlich-III methods. Commun. Soil Sci. Plant Anal. 16. 467-484. 